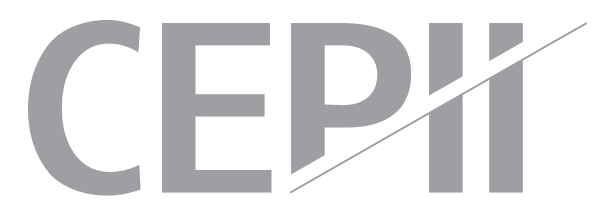

\title{
Exchange rate pass-through to import prices: Accounting for changes in the Eurozone trade structure
}

Antonia Lopez-Villavicencio \& Valérie Mignon

Highlights

- We analyze how trade with China and Eastern Europe impacts exchange rate pass-through (ERPT) into import prices for five Eurozone countries.

-We find that pass-through is complete in many cases, especially when considering Chinese imports.

- There is no compelling evidence of a generalized link between ERPT and trade liberalization.

- The launch of the single currency has not provoked a sufficient change in the part of trade exposed to exchange rate fluctuations and, therefore, has not affected the pass-through. 


\section{Abstract}

This paper assesses whether the emergence of new trading partners (i.e., China and Eastern Europe) as suppliers reduces the exchange rate pass-through (ERPT) in Eurozone countries which differ regarding their external exposure. Using bilateral data on import prices at the two-digit sector level, we find that (i) pass-through is complete in many cases, (ii) ERPT from China is higher than from the United States, and (iii) there is no compelling evidence of a generalized link between ERPT and the increasing integration of some emerging markets in European imports. We also show that the launch of the single currency has not provoked a sufficient change in the part of trade exposed to exchange rate fluctuations and, therefore, has not affected the pass-through. Overall, the trend of liberalization in new players' markets has not altered the competitive environment such as to induce exporters of other countries to absorb exchange rate depreciations.

\section{Keywords}

Exchange Rate Pass-through, Import Prices, China, Eastern Europe, Eurozone.

\section{JEL}

E31, F31, F4, C22.

\section{Working Paper}

\section{CEPI}

CEPII (Centre d'Etudes Prospectives et d'Informations Internationales) is a French institute dedicated to producing independent, policyoriented economic research helpful to understand the international economic environment and challenges in the areas of trade policy, competitiveness, macroeconomics, international finance and growth.
CEPII Working Paper

Contributing to research in international economics

C C CEPII, PARIS, 2019

All rights reserved. Opinions expressed in this publication are those of the author(s) alone.

$\begin{array}{ll}\text { Editorial Director: } & \text { CEPII } \\ \text { Sébastien Jean } & \text { 20, avenue de Ségur } \\ & \text { TSA 10726 } \\ \text { Production: } & 75334 \text { Paris Cedex } 07 \\ \text { Laure Boivin } & +33153685500 \\ & \text { www.cepii.fr } \\ \text { No ISSN: } 1293-2574 & \text { Press contact: presse@ }\end{array}$




\title{
Exchange rate pass-through to import prices: Accounting for changes in the Eurozone trade structure ${ }^{1}$
}

\author{
Antonia López-Villavicencio* and Valérie Mignon ${ }^{\dagger}$
}

\section{Introduction}

The exchange rate pass-through (ERPT from now on), understood as the extent to which an exchange rate change is reflected in import and/or consumer prices, is a central concept in international trade and macroeconomics, both from theoretical and empirical viewpoints (see Knetter, 1989; Campa and Goldberg, 2005; and Burstein and Gopinath, 2013). A large body of the related literature puts forward that ERPT is incomplete and has been steadily declining over the past few decades.

From a theoretical perspective, trade integration and liberalization, i.e., globalization, play a key role in explaining the partial and decaying character of ERPT. ${ }^{2}$ Gust, Leduc, and Vigfusson (2010) suggest that globalization induces changes in the competitive environment and forces exporters to lower markups in response to an exchange rate depreciation, thereby moderating pass-through. Under the same perspective, Bergin and Feenstra (2009) set up a theoretical two-country model and show that the fall in ERPT to import prices in the United States can be largely attributed to the increasing import penetration rate of China through two effects: (i) a direct composition effect, which comes from the renminbi's peg to the U.S. dollar (more imports from a country with a fixed exchange rate regime push ERPT down), and (ii) an indirect competition effect, which results from the fact that other

\footnotetext{
${ }^{1}$ We would like to thank Anne-Laure Delatte and Sébastien Jean for helpful remarks and suggestions.

${ }^{*}$ GATE-CNRS and University Lumière Lyon 2, France. Email: lopez@gate.cnrs.fr.

${ }^{\dagger}$ EconomiX-CNRS, University of Paris Nanterre and CEPII, France. Corresponding author: Valérie Mignon, EconomiX-CNRS, University of Paris Nanterre, 200 avenue de la République, 92001 Nanterre Cedex, France. Phone: 331409758 60. E-mail: valerie.mignon@parisnanterre.fr

${ }^{2} \mathrm{~A}$ second theoretical explanation suggests that in the context of a stable and predictable monetary policy environment, nominal shocks play a vastly reduced role in driving fluctuations in prices and in the exchange rate (Taylor, 2000). Thus, a stable monetary policy environment-supported by an institutional framework that allows the central bank to pursue a credible and independent policy-contributes to explaining why even sizable depreciations of the nominal exchange rate have exerted small effects on prices: when the inflation environment is more stable, firms resist passing exchange rate changes on to prices. However, from an empirical point of view, López-Villavicencio and Mignon (2017) show that uncertainty about domestic monetary policy does not affect the pass-through to import prices.
} 
foreign exporters need to compete with Chinese goods in the U.S. market. On the opposite, Dornbusch (1987) and Benigno and Faia (2016) argue that globalization tends to rise ERPT through the growing dependence of imported inflation on external conditions. The share of foreign products in the domestic market plays a key role in this explanation (see Section 2).

This paper falls into this strand of the literature, with the aim at shedding light on the globalization channel and, in particular, on the role played by key factors affecting the composition of trade flows in some European countries using disaggregated, good-level price data. The hypothesis we test is the indirect effect proposed by Bergin and Feenstra (2009) and Gust, Leduc, and Vigfusson (2010), i.e., whether changes in the competitive environment induce exporters from other countries to moderate pass-through.

To this end, we begin by empirically investigating the link between globalization and ERPT by paying special attention to China as source of European imports. Our motivation is in line with the evolution of the global trade pattern observed from about two decades. Indeed, since the beginning of the 2000s, all developed countries faced a stark increase in their exposure to Chinese import competition. This is especially the case for the United States, with a 25 percentage points increase in the import share of China in ten years, from 2000 to 2010. The same growing dynamics is observed in European countries with an augmentation in the Chinese import share in total imports by around $16 \mathrm{pp}$. in the United Kingdom and the Netherlands, and 14 pp. in Germany; France and Sweden being the least exposed with a share amounting at $13 \mathrm{pp}^{3}$ Although these increases are lower than for the United States, they are non-negligible and may have an impact on ERPT in European countries.

Along with the growing market shares of China in European imports, the rise of Eastern Europe is also likely to affect the European global trade pattern. This evolution is of particular interest as the emergence of China occurred shortly after trade was liberalized with the former planned economies after the fall of the Berlin wall. As neighboring countries, Eurozone members may have been impacted by the liberalization of markets in Eastern Europe, particularly the Czech Republic and Poland. We therefore consider if this similar and pronounced increase in the shares of these new players affects the elasticity of import prices to exchange rate movements.

${ }^{3}$ These statistics are extracted from Marin (2017). 
A final major feature that has shaped the interconnection of European countries with their external environment is the processes set in motion by the introduction of the euro. Mechanically, if countries have a higher proportion of imports in their own currency, ERPT should decrease. Given that trade barriers have been removed and euro adopted as a common currency in the European Monetary Union (EMU), there is, in principle, a smaller share of "output" exposed to exchange rate fluctuations. ${ }^{4}$ These characteristics should affect the way foreign firms pass exchange rate shocks onto prices as they reduce the market power of exporters outside the euro area. As such, the transmission of exchange rate variations into import prices would have declined as the proportion of Eurozone final demand satisfied with extra-EMU imports diminished (see, e.g., Faruqee, 2004 and Campa, Goldberg, and Gonzàlez-Mínguez, 2005).

Therefore, we study if the three aforementioned parallel shocks, namely (i) the emergence of China, (ii) Eastern countries' integration and (iii) the launch of the single currency, are helpful to explain the role of the exchange rate for European import prices. We consider both globalization and regional integration, i.e., interaction with distant countries as well as relations to neighboring nations. In addition to overcoming the drawback linked to the short time sample used in previous studies for the euro area context ${ }^{5}$ (with the exception of Ben Cheikh and Rault, 2016), we go further than the existing literature in various ways.

First, we confront five European economies that differ regarding their external exposure and the share of imports invoiced in euro. The comparison is interesting since, in principle, a relatively low dispersion of ERPT levels is expected in the euro area due to the anticipated convergence process implied by the monetary union (see, e.g., Ben Cheikh and Rault, 2016). ${ }^{6}$ However, in reality, some countries are more insulated from exchange rate shocks, while others are highly sensitive to them. For instance, France is not only characterized by a low degree of openness to imports, but also by having a growing share of its trade denominated in euro. Austria and Belgium, while being both highly opened, differ considerably regarding the share of imports invoiced in their own currency. Finland, in turn, has a low degree of openness but an overwhelming share of its imports is priced in a foreign currency. Finally, Germany is at an intermediate level corresponding to the EMU aggregate openness degree.

\footnotetext{
${ }^{4}$ Some studies suggest that the creation of EMU might have stimulated intra-area trade at the expense of that taking place with the rest of the world. See, for instance, Faruqee (2004).

${ }^{5}$ See, e.g., Schroder and Hufner (2002), Anderton (2003), Hahn (2003), Campa, Goldberg, and GonzàlezMínguez (2005), Campa and Gonzàlez-Mínguez (2006), Faruqee (2006), and Ben Cheikh and Rault (2016). ${ }^{6}$ It is worth mentioning that this argument may be counterbalanced by the fact that countries may also become more differentiated, due to rising specialization across euro area countries (see Krugman and Venables, 1996).
} 
Second, we present an overview of the exposure to Chinese, Eastern European and Eurozone countries import competition by sector for our selected European member states since 2000. We further assess the effect of trade liberalization on bilateral ERPT by addressing the competitive impact of growing market shares of the new players together with the changing proportion of imports with other EMU members - three trade shocks that have not been simultaneously studied in the previous literature.

Third, we avoid two types of aggregation bias. The first one has been largely discussed in the literature-especially in the context of the purchasing power parity hypothesis ${ }^{7}$ - and concerns the bias due to the use of aggregated price series (see, e.g., Pesaran and Smith, 1995, and Mumtaz, Oomen, and Wang, 2006). Moreover, aggregated pass-through could also arise from the compositional change in import bundles over time as the level of ERPT varies dramatically across sectors (e.g., Devereux and Yetman, 2010). To avoid this bias, we rely on disaggregated, good-level manufacturing industries based on the two-digit Standard International Trade Classification (SITC). Those data enable us to compare ERPT coefficients across manufacturing goods, which is highly relevant since European countries tend to import textiles, toys and computer equipment from China (miscellaneous and manufactured goods), while they import cars and car parts from Eastern Europe (see Figure 2). The second bias may arise by aggregating import prices and bilateral exchange rates across countries. Indeed, ERPT is usually summarized by the coefficient obtained using sectoral, multilateral price indices and effective exchange rates. By doing so, the consensus in the literature is that the estimated short-run ERPT is incomplete. ${ }^{8}$ However, ERPT to import prices should not only depend on cross-sectoral characteristics but also on specificities from both exporting and importing countries due to, for instance, different pricing strategiesproducer versus local currency prices-, pricing-to-market behavior of firms, etc. ${ }^{9}$

Therefore, we concentrate on bilateral relations with main trading partners, namely China, Japan, the United Kingdom, and the United States. ${ }^{10}$ Employing bilateral data is crucial since it allows us to distinguish the effects of exchange rates on unit values at the level

\footnotetext{
${ }^{7}$ See Chen and Engel (2005), Imbs, Mumtaz, Ravn, and Rey (2005), and Gadea and Mayoral (2009).

${ }^{8}$ Using effective exchange rates and import prices, Campa, Goldberg, and Gonzàlez-Mínguez (2005) show that short-run ERPT is high, although incomplete, and that it differs across industries and countries.

${ }^{9}$ Gopinath, Itskhoki, and Rigobon (2010) show substantial differences in ERPT rates regarding the specific U.S. trading partner. For instance, the average pass-through rate for German imports into the U.S. is $63 \%$ $(17 \%)$ higher for dollar priced (non-dollar priced) goods compared to imports from the United Kingdom. ${ }^{10}$ We select these four countries as the EU-28 (including U.K.), China, the United States, and Japan are the largest global players for international trade goods (source: Eurostat).
} 
of country pairs. To give a concrete example, consider the case of France with two trading partners, the U.S. and Japan. It is well known that ERPT could be very high, even complete, if exporters set prices in their own currencies-the so-called "producer currency pricing" strategy. However, exchange rate movements are not necessary transmitted to consumer prices if exporters set prices in euro-the so-called "local currency pricing" strategy. As shown in Table 1, more than half of extra-EU imports in France are invoiced in U.S. dollar, and less than 5 percent in currencies other than euro or dollar-yuan, yen, etc. As a consequence, the prices paid by consumers for imported goods which are invoiced in other currencies than the U.S. dollar or the euro are not much influenced by changes in the exchange rates. In other words, when the local currency pricing strategy dominates, the channels for adjustment through relative price changes are considerably narrowed. It is then expected to find a higher pass-through for U.S. than for Japanese imports to France.

Relying on quarterly data over the 2000Q1-2018Q3 period, our main findings can be summarized as follows. First, the incomplete ERPT suggested in the literature is not a general result. On the contrary, exchange rate changes are fully reflected in bilateral import prices in many cases, especially when considering Chinese import prices. Second, interacting exchange rate changes with our trade competition indicators shows the absence of a generalized link between trade liberalization and ERPT. Indeed, ERPT is neither related to China's gains in market shares nor to Eastern European surging exports to Europe. Finally, the launch of the single currency has not significantly reduced the share of trade exposed to exchange rate fluctuations.

This paper is organized as follows. Section 2 briefly reviews the literature and the main mechanisms through which globalization may affect ERPT. Section 3 describes our methodology. Section 4 presents the data and some stylized facts. Section 5 displays our estimation results, and Section 6 concludes the paper.

\section{A brief review of literature}

Two theoretical effects of trade integration on ERPT are at play. According to the first effect, globalization impacts inflation dynamics through its influence on the degree of competition. Specifically, globalization - which refers here to a rising share of goods sold by foreign firms in the domestic market or factors leading to higher trade integration-impacts imported inflation dynamics through its effect on ERPT into import prices. As a large fraction of consumption and intermediate goods is represented by imported goods, the overall price index becomes more sensitive to external conditions, namely the combined dynamics of nominal exchange rate and foreign marginal costs. The second channel through which 
globalization influences the dynamics of inflation is, indirectly, via its effect on the pricing strategies of domestic firms selling in the internal market.

While these theoretical effects are clearly established, their outcome is controversial. Specifically, both higher and lower ERPT may result from greater competition. Following Dornbusch (1987) and Benigno and Faia (2016), globalization reflected by greater competition implies higher ERPT. The intensity of ERPT depends on the degree of concentration in the market and, in particular, on the share of foreign products in the domestic market. Indeed, greater competition, due to the rise in the share of foreign products sold in a specific industry raises the degree of exchange rate pass-through. Following this mechanism, globalization accentuates the dependence of imported inflation on external conditions, and Benigno and Faia (2016) show that there is evidence of an increase in ERPT degree exactly at the time at which the globalization process took place. Their theoretical results are confirmed by an empirical analysis on U.S. sectoral data providing evidence that ERPT has increased in at least half of the sectors considered, especially after 1999, i.e., after the pick up of trade liberalization.

On the opposite, Gust, Leduc, and Vigfusson (2010) argue that greater competition implies

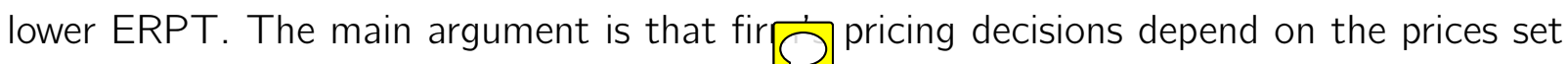
by its competitors. This feature implies that a foreign exporter finds it optimal to vary its markup in response to shocks that change the exchange rate, insulating import prices from exchange rate movements. With increased trade integration, exporters have become more responsive to the prices of their competitors and this change in pricing behavior may contribute to the observed decline in the sensitivity of import prices to the exchange rate (Gust, Leduc, and Vigfusson, 2010). Therefore, in a model with strategic complementarity, factors that lead to greater trade integration may reduce pass-through to prices. In their model, similar to Dornbusch (1987), the entry of foreign exporters, other things being equal, leads to a rise in ERPT. However, they show that following a reduction in the cost of exporting, the effects of markup adjustments that arise only along the intensive margin largely dominate the impact of entry on pass-through. Gust, Leduc, and Vigfusson (2010) provide empirical evidence linking the fall in pass-through to lower trade costs. Using industry-specific measures of pass-through and trade costs, they show that industries in which the decline in trade costs has been relatively large have also experienced quite important decreases in pass-through.

Equally, in Bergin and Feenstra (2009) the fall in ERPT in the United States is largely attributed to the increasing import penetration rate of China. In their theoretical model, 
changes in the competitive environment induce exporters from other countries to lower markups following an exchange rate depreciation under three conditions: (i) there is a local bias, (ii) the number of firms varies due to free entry, and (iii) the increase in China's share comes from the existence of more Chinese exporting firms. If the number of these firms is fixed but if each of them has higher share, then the pass-through will increase. In other words, ERPT is lowered by a high number of competing firms active in the U.S. market, rather than by a large Chinese market share per se.

As shown, the debate related to the theoretical impact of globalization on ERPT is far from being closed. Turning to an empirical viewpoint, the literature that explores the link between globalization and ERPT is very scarce, especially in the non-U.S. case. Our aim in this paper is to fill this gap by running an empirical analysis focusing on countries belonging to the Eurozone. As import prices constitute a major transmission channel of changes in the euro on domestic prices and, in turn, inflation and output, analyzing ERPT is of crucial importance in the context of a monetary union. The same exchange rate change may affect Eurozone countries differently, depending on their external exposure. Accounting for such different responses of import prices to euro exchange rate changes is important for the conduct of the single monetary policy. It is also worthy of interest with regard to the impact of entering into the union and the success of protocols and processes calling for structural reforms in the EMU.

\section{Methodology}

We estimate bilateral exchange rate pass-through by considering the following equation:

$$
\Delta m p_{i, t}=\alpha+\sum_{j=1}^{n} \gamma_{j} \Delta m p_{i, t-j}+\rho \Delta y_{i, t}+\lambda \Delta m c_{i, t}^{*}+\theta \Delta e_{i, t}+\epsilon_{i, t}
$$

where $m p$ represents the import price index in the destination country of sector i's products from its trading partner, i.e., country-pair import price index, $y$ is a local demand factor, $m c^{*}$ stands for the exporter marginal cost (i.e., the foreign production costs), $e$ is the bilateral exchange rate, $i$ denotes the industry and $t$ refers to the period. Our primary concern in this equation is the pass-through elasticity which corresponds to the coefficient on the exchange rate change, namely $\theta$. The case $\theta=1$ refers to a complete ERPT, corresponding to a one-for-one pass-through changes in import prices. Incomplete ERPT occurs when $\theta<1$, i.e., when exporters adjust their markup. Note that Equation (1) is estimated at the 
product level using individual fixed effects. All the variables are expressed in logarithms.

To explore the rise in competition dimension of pass-through, our empirical strategy consists in extending the benchmark ERPT equation as follows:

$$
\begin{aligned}
\Delta m p_{i, t}= & \alpha+\sum_{j=1}^{n} \gamma_{j} \Delta m p_{i, t-j}+\rho \Delta y_{i, t}+\lambda \Delta m p_{i, t}^{*}+\theta \Delta e_{i, t} \\
& +\theta^{C H I N A}\left(\Delta e_{i, t} \times \mathrm{CHINA}_{i, t}\right)+\delta^{C H I N A} \mathrm{CHINA}_{i, t} \\
& +\theta^{E E C}\left(\Delta e_{i, t} \times \mathrm{EEC}_{i, t}\right)+\delta^{E E C} \mathrm{EEC}_{i, t} \\
& +\theta^{E U R O}\left(\Delta e_{i, t} \times \mathrm{EURO}_{i, t}\right)+\delta^{\text {EURO } \mathrm{EURO}_{i, t}+\epsilon_{i, t}}
\end{aligned}
$$

Three indicators of trade competition are considered: changes in the import penetration rates of China (CHINA) and Eastern European countries (EEC), and a measure of regional trade $(E U R O)$, i.e., change in the share of intra-EMU imports over total imports. In Equation (2), we interpret a significant coefficient $\theta^{C H I N A}, \theta^{E E C}$ or $\theta^{E U R O}$ as evidence that ERPT is affected by the previous integration/regionalization shocks.

\section{Data}

\subsection{Time sample}

The period covered in the present study depends on both the availability and the level of disaggregation of data. Indeed, exchange rate pass-through estimates in the literature are usually confronted with a trade-off between sectoral disaggregation level of data and period coverage (Gaulier, Lahrèche-Révil, and Méjean, 2008). Basically, estimates based on aggregated price data allow for a larger time span coverage. However, the use of aggregated price series limits the possibility to identify the structural determinants of the pass-through (to detect differences regarding price discrimination or product differentiation for instance). Working on disaggregated price data offers more information at the product or good level, but has a cost in terms of data period availability. In this paper, we rely on disaggregated data for five Eurozone countries, namely Austria, Belgium, Germany, Finland and France vis-à-vis their main trading partners-China, Japan, the U.K. and the U.S.- over the period 2000Q1-2018Q3. 


\subsection{Variables}

Regarding the measure of import prices at the disaggregated (i.e., good) level, we construct quarterly bilateral import unit value indices in manufactured goods (SITC categories 5 to 8). ${ }^{11}$ The series are computed from data on values and quantities provided by the Eurostat Comext database. Sub-sections (i.e., panel members) correspond to two-digit sectors or aggregations of them.

In Equation (1), both marginal costs and importer's demand characteristics are highly difficult to evaluate since they are not directly observable, so the use of proxies is common in the literature. In our specification, in the spirit of Marazzi, Sheets, Vigfusson, Faust, Gagnon, Marquez, Martin, Reeve, and Rogers (2005) and Marazzi and Sheets (2007), we take GDP growth from the partner country as the proxy for production costs. For the local demand factor, we use domestic GDP growth as it is usually done in the literature (see, e.g., Campa, Goldberg, and Gonzàlez-Mínguez, 2005). The exchange rate corresponds to the bilateral exchange rate, with an increase in the index indicating a depreciation.

Finally, to evaluate how China's and Eastern Europe's presence in total imports may have affected the pricing decisions of exporters from other countries, we consider their import share over total imports in each SITC sector. ${ }^{12}$ Regarding our measure of intra-euro trade, it is defined as the ratio of Eurozone imports over total imports.

\subsection{Some brief stylized facts}

Figures 1 and 2 display the evolution of our three trade competition indicators. As shown by Figure 1, intra-EMU imports are quite stable over the period in all sectors-except in Germany where they tend to decrease slightly. Their share amounts at more than $50 \%$ in several sectors. However, note that the share of intra-EMU imports differs among sectors and countries: for instance, about $80 \%$ of Austria's and France's total imported manufactured products come from other countries sharing the same currency, i.e., euro. This share is much lower for Belgium and Finland. Intra-EMU imports of transport and equipment

\footnotetext{
${ }^{11}$ The considered sectors are: SITC 5: Chemicals and related products; SITC 6: Manufactured goods; SITC 7: Machinery and transport equipment; SITC 8: Miscellaneous manufactured articles. We focus on those sectors as they correspond to the products for which the shares in trade are the highest- the shares of raw materials, food and drink, and energy being indeed very low compared to chemicals, other manufactured goods, and machinery and vehicles.

${ }^{12}$ The group of Eastern European countries includes Czech Republic and Poland, the two main partners from this region.
} 
and miscellaneous manufactured goods in Germany, on the contrary, are very low compared to the other countries. These differences in trade exposure to exchange rate fluctuations should, in principle, be reflected in the exchange rate pass-through of each country/sector.

Figure 2 illustrates that China's and Eastern Europe's import shares have increased in all sectors throughout the period. In many cases, imports from Eastern European countries are higher than from China: there seems to be a "local bias" that favors European goods over Chinese ones due to Eastern Europe proximity with Austria and Germany. In this case, albeit the increase in China's share, Chinese exporters should absorb exchange rate shocks lowering their pass-through: the rise in competition forces all firms to lower their markups. It is worth mentioning that even if the share of China in EMU trade has strongly increased since the beginning of the 2000s, it remains quite low in comparison with the U.S.-China trade level.

\section{Results}

\subsection{Estimated ERPT}

Let us first consider the estimation of our baseline Equation (1). The corresponding results are reported in Table $2 .^{13}$ In line with previous studies, we find that the effect of exchange rate shocks differs strongly across countries and sectors. This heterogeneity between countries can be explained by the fact that industries concerned with manufactured goods are more oriented towards product differentiation, leading to distinct ERPT degrees in different nations. Note also that pass-through from Chinese and U.S. imports to all the countries in our sample is higher compared to Japanese or British ones which, in fact, are negligible on average. With these two countries, there seems to be a local currency pricing strategy where exporting firms adapt their markups depending on the destination market to offset completely or partially the exchange rate movements. In an open economy general equilibrium framework, Bacchetta and van Wincoop (2003) show that firms facing strong competition in foreign markets are more likely to price in local currency.

Trade flows involving China as a trading partner are of particular interest. Indeed, exchange rate pass through into Chinese import prices is specially high, sometimes complete, even in cases where the trade prices do not depend on the dollar exchange rate. As an exam-

\footnotetext{
${ }^{13}$ We use the one-step GMM estimator for dynamic panel data with fixed effects. The equations are then estimated for each SITC sector and the panel members are the divisions in each Section. We use the first lags of dependent and independent variables as instruments.
} 
ple, consider the case of miscellaneous manufactured goods. As shown, there is a large difference in the pass-through of the yuan versus the dollar: the ERPT coefficient is not statistically different from one for Finish, French and German import prices, whereas it amounts only at around 0.6 for the dollar in the cases of Finland and France and is very low for Germany. In other words, considering that the yuan is pegged to the dollar, a one percent depreciation of the dollar increases U.S. import prices by 0.6 , but is fully reflected in Chinese import prices. These findings are important for at least two reasons, highlighting notably our contribution to the existing literature in using bilateral data. First, our results contradict previous evidence of incomplete ERPT from studies relying on multilateral relations. ${ }^{14}$ Actually, disaggregating by country pairs reveals large differences that need to be considered when assessing the degree of ERPT. In other words, our results show that failing to account for this heterogeneity tends to bias the pass-through estimates and, in turn, leads to erroneous conclusions. Indeed, as illustrated by the estimated elasticities at the multilateral level in the last panel of Table 2, ERPT is incomplete at this level of aggregation. Consequently, aggregating trade partners by reasoning at a multilateral level may obscure important country-level differences, leading to a biased estimation of the elasticity of imports to exchange rate changes.

Second, our findings provide evidence of an important influence of Chinese exporters. This power allows them to pass exchange rate shocks into their international prices, even if (i) the U.S. dollar and the euro are the main currencies in the invoicing of international trade and the worldwide use of the Chinese renminbi (RMB), while expanding, remains for the time quite limited, and (ii) the RMB was pegged to the U.S. dollar. Our result of a higher pass-through from China than from the U.S. in many cases challenges Gopinath (2015)'s proposition that the dollar exchange rate dominates the bilateral exchange rate in the passthrough into prices.

\subsection{Accounting for changing market shares}

Let us now assess how changes in the structure of euro-area trade affect ERPT at the industry and country level. We concentrate on bilateral relationships with China and the U.S. since, contrary to Japan and the U.K., they present a positive and significant passthrough - a positive sign of the ERPT is indeed expected as an increase in the nominal exchange rate translates into a depreciation of the currency and should be normally followed by a rise in prices. Table 3 displays the main estimation results of Equation (2).

${ }^{14}$ See Menon (1995) and Engel (2002) for a survey, and Campa and Goldberg (2005), Marazzi and Sheets (2007), Bouakez and Rebei (2008), or Gust, Leduc, and Vigfusson (2010) and Ben Cheikh and Rault (2016) for more recent empirical studies. 
As shown, there is no clear-cut evidence on how liberalization with China and/or Eastern European economies affects the way foreign exporters pass-through costs shocks to their prices.

Let us first consider the case of China as a new key player in world trade. Our findings illustrate two effects. First, Chinese firms' pass-through exchange rate variations into their prices regardless of any change in their own market share. Moreover, Chinese pass-through is independent of other countries' changing market shares. Second, the increased role of China as a source of European imports has not lowered pass-through of other countries, with the notable exception of Germany: U.S. pass-through is lowered by a high number of competing Chinese firms. The particular case of Germany may be related to the large size of the country that places this nation as an important destination market; this country having the highest share of extra-EU trade among the EU member states in 2018 (source: Eurostat). Following Marazzi and Sheets (2007), two main explanations may be at play in this case: (i) the effects of direct competition with China, making exporters from other countries hesitant to shift their dollar prices in response to fluctuations in their exchange rates, i.e., active pricing-to-market strategies of U.S. exporters to defend their market shares, and (ii) the threat of potential competition from Chinese firms.

It is worth mentioning that we could have expected a more pronounced impact of rising competition from China. However, as previously mentioned, the bulk of literature dealing with such "Chinese effect" concerns the United States, i.e., a country in which imports from China represent around $22 \%$ of its total imports in 2017. For the European countries under investigation here, these shares are much lower: between 4\% (Belgium) and 10\% (Germany) for the same year. ${ }^{15}$ Thus, Eurozone countries' China exposure is less stark compared to the United States, which may explain the lack of significant effect on ERPT.

Turning to the role of Eastern Europe, note that such effect cannot be observed for the United States as its trade with this region is negligible. On the contrary, for European countries, trade with these nations is higher than with China in some cases (see Figure 2). Despite these trade flows, we do not find evidence of a significant effect of Eastern Europe on ERPT. One explanation may come from the important role of Global Value Chains (GVCs), especially in the German case. As shown by Marin (2011), Eastern Europe was a skill-rich region in terms of labor, thus offering not only new market opportunities for German firms, but also a pool of skilled and inexpensive workers. This led to the development of German value chains to Eastern Europe after the beginning of the 1990s, and helped

\footnotetext{
${ }^{15}$ These figures are based on data extracted from the International Trade Center.
} 
Germany to keep costs down and to win market shares globally (Marin, 2010). Overall, the expansion of GVCs between Eurozone members and Eastern European countries helped the former faring better than the United States with China's competition as, on the import side, trade adjustment to low-cost competition had already happened before the rise of the Chinese economy.

Finally, as an illustration that globalization can act in different ways and has many sides, our findings show that there is no overall evidence that the launch of the single currency has had a major impact on ERPT in most manufacturing industries. This result is in line with the pattern observed in Figure 1. Indeed, the share of intra-EMU imports has remained steady over the period under study, or even decreased. This implies that even with the introduction of the euro, the share of trade being affected by exchange rate fluctuations is stable. Note, however, the positive and significant sign of the interaction term in the chemistry industry in Finland, France and Germany. This result surprisingly uncovers that the decreasing trade with other EMU-member countries in the chemistry industry can even reduce the dollar ERPT to U.S. import prices. One possibility is that a lower share of imports in euro implies a higher share of other new players in euro-area imports. This risk enhances the fall in pass-through of advanced countries via active pricing-to-market strategies of exporters to defend their market shares.

In sum, our results show that movements in bilateral exchange rates have an important impact on European import prices, specially with China. However, the extent of exchange rate pass-through is not affected by shifts in the geographical composition of trade flows in Europe.

\section{Conclusion}

The sustained economic globalization process of the last decades has been accompanied by profound changes in international trade. Among all of them, the rise in the number of foreign products in domestic markets together with higher competition between domestic and foreign firms are a few examples. One particular aspect that has received a lot of attention is the stark augmentation in the exposure to Chinese import competition. The case of Eastern Europe is also worthy of interest as its market share in EMU imports has more than doubled in the past decade.

This sharp increase in trade liberalization in recent years has been coupled with an important decline in ERPT to multilateral import prices. These simultaneous dynamics suggest 
that the evolution of ERPT cannot be dissociated from the process of globalization. We tackle this issue in the present paper by analyzing how trade with China and Eastern Europe impacts ERPT into import prices for five Eurozone countries, namely Austria, Belgium, Finland, France and Germany, which are characterized by different external exposures. Given the growing share of China and Eastern Europe in EMU trade, having precise knowledge of their impact on ERPT degree is of high policy relevance.

Our findings differ from the previous literature in two main aspects. First, ERPT to import prices is very high, even complete, in some cases. This is specially true with Chinese imports, which are highly related to exchange rate movements even in cases of low pass-through of the U.S. dollar. Second, contrary to the abundant literature showing that the pass-though decline in the United States stems from a rise in the share of trade in several emerging markets, our findings emphasize that liberalization has played very little in explaining ERPT. Indeed, we show that the pass-through is neither related to China's gains in market shares, nor to the Eastern European surging exports to Europe. Moreover, the launch of the single currency has not provoked a sufficient change in the part of trade exposed to exchange rate fluctuations.

Our results are important because they uncover important heterogeneities among European countries. They also suggest that the pass-through to European import prices may specially be related to other factors. A further explanation to the fact that increases in China's or Eastern Europe's shares do not damp pass-through is that their presence has not affected the competitive environment: for instance, if China's growing share comes from the same number of firms selling but each of them having higher shares, then pass-through will increase despite the rise in the Chinese share (Bergin and Feenstra, 2009).

Overall, our results show that ERPT into import prices is mostly significant, meaning that exchange rate changes still exert important pressure on domestic prices, even after accounting for the effects of globalization. Furthermore, the responses of import prices to exchange rate variations differ across countries and sectors, a characteristic which has to be taken into account for the conduct of the single monetary policy. 


\section{References}

Anderton, R. (2003): "Extra-euro area manufacturing import prices and exchange rate pass-through," Working Paper Series 0219, European Central Bank.

Bacchetta, P., and E. van Wincoop (2003): "Why do Consumer Prices React Less Than Import Prices to Exchange Rates?," Journal of the European Economic Association, $1(2 / 3), 662-670$.

Ben Cheikh, N., and C. Rault (2016): "Recent estimates of exchange rate pass-through to import prices in the euro area," Review of World Economics (Weltwirtschaftliches Archiv), 152(1), 69-105.

Benigno, P., and E. Faia (2016): "Globalization, Pass-Through, and Inflation Dynamics," International Journal of Central Banking, 12(4), 263-306.

Bergin, P. R., and R. C. Feenstra (2009): "Pass-Through of Exchange Rates and Competition between Floaters and Fixers," Journal of Money, Credit and Banking, 41(s1), $35-70$.

Bouakez, H., and N. Rebei (2008): "Has exchange rate pass-through really declined? Evidence from Canada," Journal of International Economics, 75(2), 249 - 267.

Burstein, A., and G. Gopinath (2013): "International Prices and Exchange Rates," NBER Working Papers 18829, National Bureau of Economic Research, Inc.

Campa, J., and L. Goldberg (2005): "Exchange Rate Pass-Through into Import Prices," The Review of Economics and Statistics, 87(4), 679-690.

Campa, J., and J. M. Gonzàlez-Mínguez (2006): "Differences in exchange rate pass-through in the euro area," European Economic Review, 50(1), 121-145.

Campa, J. M., L. S. Goldberg, and J. M. Gonzàlez-Mínguez (2005): “Exchange-Rate PassThrough to Import Prices in the Euro Area," Working Paper 11632, National Bureau of Economic Research.

Chen, S.-S., and C. Engel (2005): "Does 'Aggregation bias' esplain the PPP puzzle?," Pacific Economic Review, 10(1), 49-72.

Devereux, M. B., and J. Yetman (2010): "Price adjustment and exchange rate passthrough," Journal of International Money and Finance, 29(1), 181-200.

Dornbusch, R. (1987): "Exchange Rates and Prices," American Economic Review, 77(1), 93-106.

Engel, C. (2002): "The responsiveness of consumer prices to exchange rates and the implications for exchange rate policy: a survey of a few recent new-open-economy models," Working Paper No. 8725, NBER.

Faruqee, H. (2004): "Measuring the Trade Effects of EMU," IMF Working Papers 04/154, International Monetary Fund. 
(2006): "Exchange Rate Pass-Through in the Euro Area," IMF Staff Papers, 53(1), 63-88.

Gadea, M. D., and L. Mayoral (2009): "Aggregation is not the solution: the PPP puzzle strikes back," Journal of Applied Econometrics, 24(6), 875-894.

Gaulier, G., A. Lahrèche-Révil, and I. Méjean (2008): "Exchange-rate pass-through at the product level," Canadian Journal of Economics, 41(2), 425-449.

Gopinath, G. (2015): “The International Price System," NBER Working Papers 21646, National Bureau of Economic Research, Inc.

Gopinath, G., O. Itskhoki, and R. Rigobon (2010): "Currency Choice and Exchange Rate Pass-Through," The American Economic Review, 100(1), 304-336.

Gust, C., S. Leduc, and R. Vigfusson (2010): "Trade integration, competition, and the decline in exchange-rate pass-through," Journal of Monetary Economics, 57(3), 309 324.

Hahn, E. (2003): "Pass-through of external shocks to euro area inflation," Working Paper Series 0243, European Central Bank.

Imbs, J., H. Mumtaz, M. O. Ravn, and H. Rey (2005): “'Aggregation Bias' DOES Explain the PPP Puzzle," CEPR Discussion Papers 5237, C.E.P.R. Discussion Papers.

Knetter, M. M. (1989): "Price Discrimination by U.S. and German Exporters," American Economic Review, 79(1), 198-210.

Krugman, P., and A. J. Venables (1996): "Integration, specialization, and adjustment," European Economic Review, 40(3), 959 - 967, Papers and Proceedings of the Tenth Annual Congress of the European Economic Association.

López-Villavicencio, A., and V. Mignon (2017): "Exchange rate pass-through in emerging countries: Do the inflation environment, monetary policy regime and central bank behavior matter?," Journal of International Money and Finance, 79(C), 20-38.

Marazzi, M., and N. Sheets (2007): "Declining exchange rate pass-through to U.S. import prices: The potential role of global factors," Journal of International Money and Finance, 26(6), $924-947$.

Marazzi, M., N. Sheets, R. Vigfusson, J. Faust, J. Gagnon, J. R. Marquez, R. Martin, T. A. Reeve, and J. Rogers (2005): "Exchange rate pass-through to U.S. import prices: some new evidence," International Finance Discussion Papers 833, Board of Governors of the Federal Reserve System (U.S.).

Marin, D. (2010): "Germany's super competitiveness: A helping hand from Eastern Europe," VOX CEPR Policy Portal, VOX.

(2011): "The Opening Up of Eastern Europe at 20: Jobs, Skills and Reverse Maquiladoras in Austria and Germany," in International Handbook on the Economics of 
Integration, Volume II, Chapters, chap. 13. Edward Elgar Publishing. VOX.

Menon, J. (1995): "Exchange rate pass-through," Journal of Economic Surveys, 9(2), 197-231.

Mumtaz, H., O. Oomen, and J. Wang (2006): “Exchange rate pass-through into UK import prices," Bank of England working papers 312, Bank of England.

Pesaran, M., and R. Smith (1995): "Estimating long-run relationships from dynamic heterogeneous panels," Journal of Econometrics, 68(1), 79 - 113.

Schroder, M., and F. P. Hufner (2002): "Exchange rate pass-through to consumer prices: a European perspective," ZEW Discussion Papers 02 20, ZEW, Center for European Economic Research.

Taylor, J. B. (2000): "Low inflation, pass-through, and the pricing power of firms," European Economic Review, 44(7), 1389-1408. 
Table 1 - EU imports, shares by invoicing currency

\begin{tabular}{c|ccccc}
\hline \hline & \multicolumn{5}{|c}{ Euro } \\
& Austria & Belgium & Germany & France & Finland \\
\hline 2010 & 58.6 & 44.5 & 49.1 & 38.9 & 42 \\
2012 & 62.4 & 36.4 & 50.9 & 39.6 & 27 \\
2014 & 59.9 & 33.3 & 50.3 & 41 & 25.8 \\
2016 & 55.2 & 37.1 & 48.4 & 43.2 & 29.9 \\
2017 & 56.2 & - & 47.1 & - & 31.9 \\
\hline \hline & \multicolumn{5}{|c}{ U.S. dollar } \\
& Austria & Belgium & Germany & France & Finland \\
\hline 2010 & 25.6 & 51.3 & 44.9 & 56.5 & 55 \\
2012 & 22.9 & 59.7 & 42.9 & 56 & 69.5 \\
2014 & 25.4 & 62 & 43.7 & 55.6 & 70.6 \\
2016 & 28.3 & 58.9 & 44.2 & 52.4 & 54.7 \\
2017 & 27.6 & - & 45.8 & - & 63.6 \\
\hline \hline & \multicolumn{5}{|c}{ Other currencies } \\
& Austria & Belgium & Germany & France & Finland \\
\hline 2010 & 14.9 & 2.5 & 5.7 & 3.3 & 2.8 \\
2012 & 13.9 & 2.5 & 5.9 & 3.0 & 3.4 \\
2014 & 13.8 & 2.4 & 5.6 & 3.0 & 3.5 \\
2016 & 15.7 & 2.1 & 7.1 & 3.9 & 5.3 \\
2017 & 15.3 & - & 6.8 & - & 4.4 \\
\hline \hline
\end{tabular}

Note: This table displays the shares by invoicing currency of extra-EU trade by member state. Source: Eurostat. 


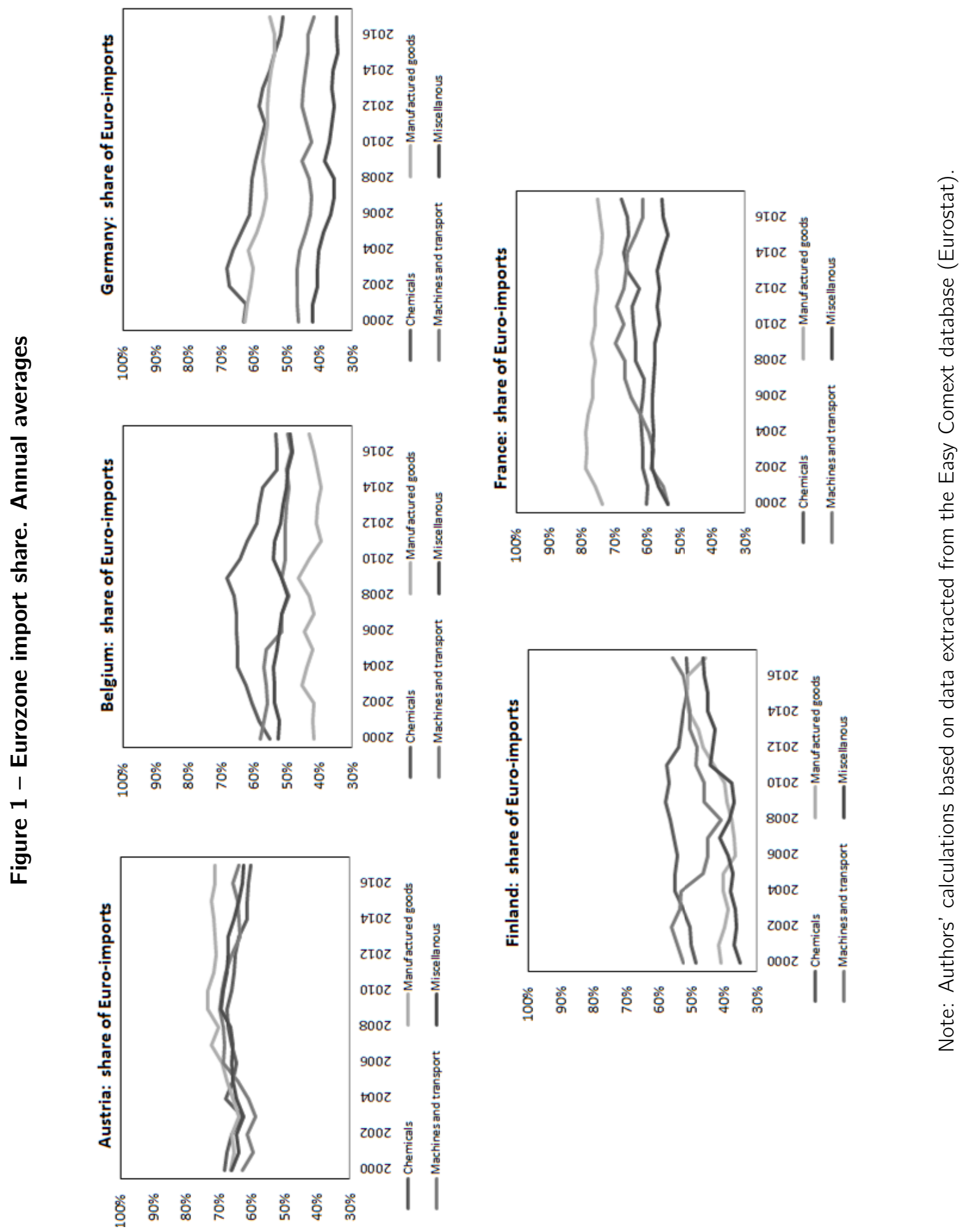


Figure 2 - China and East Europe import shares. Annual averages
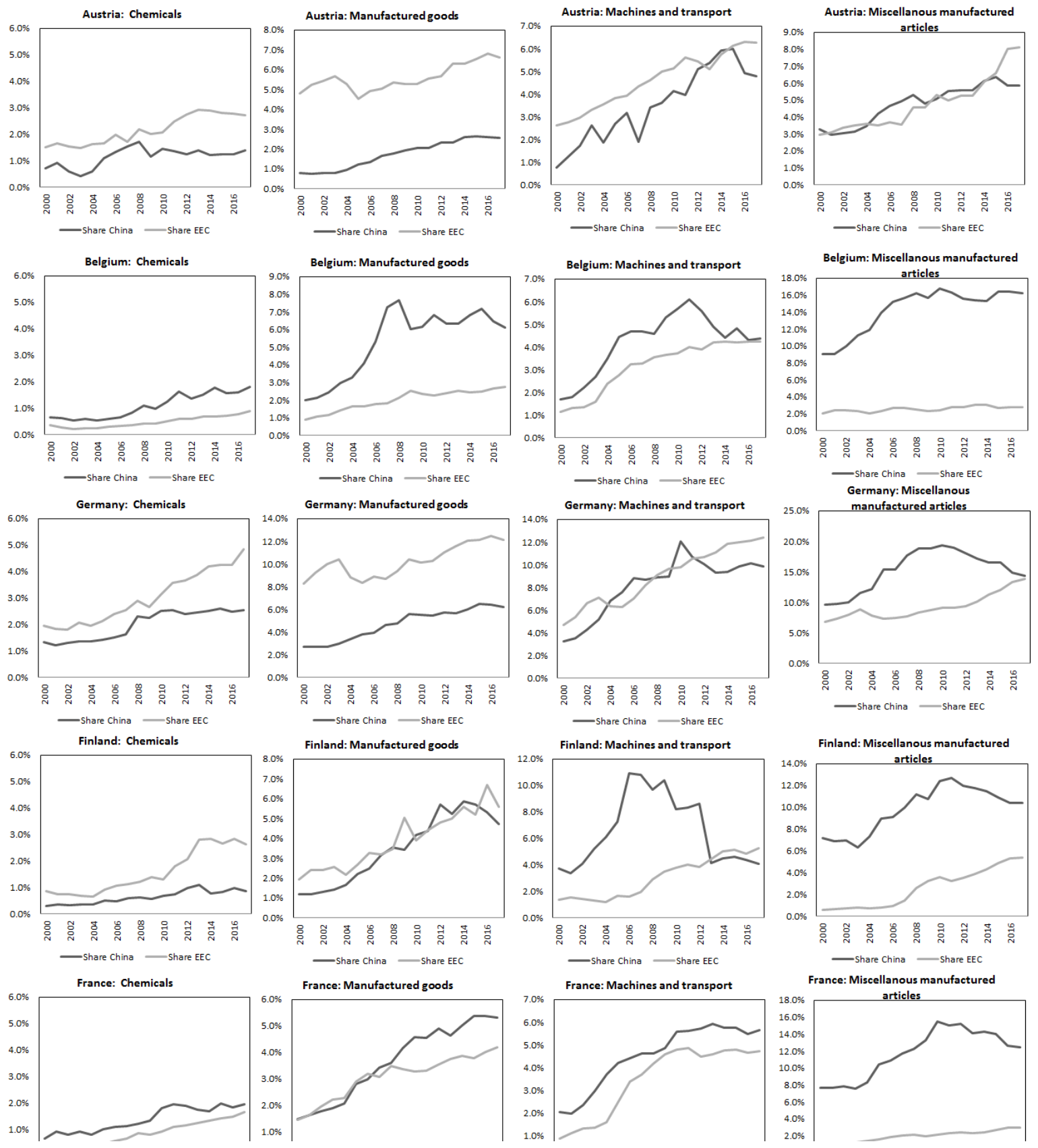

Note: Authors' calculations based on data extracted from Eurostat Comext database. 


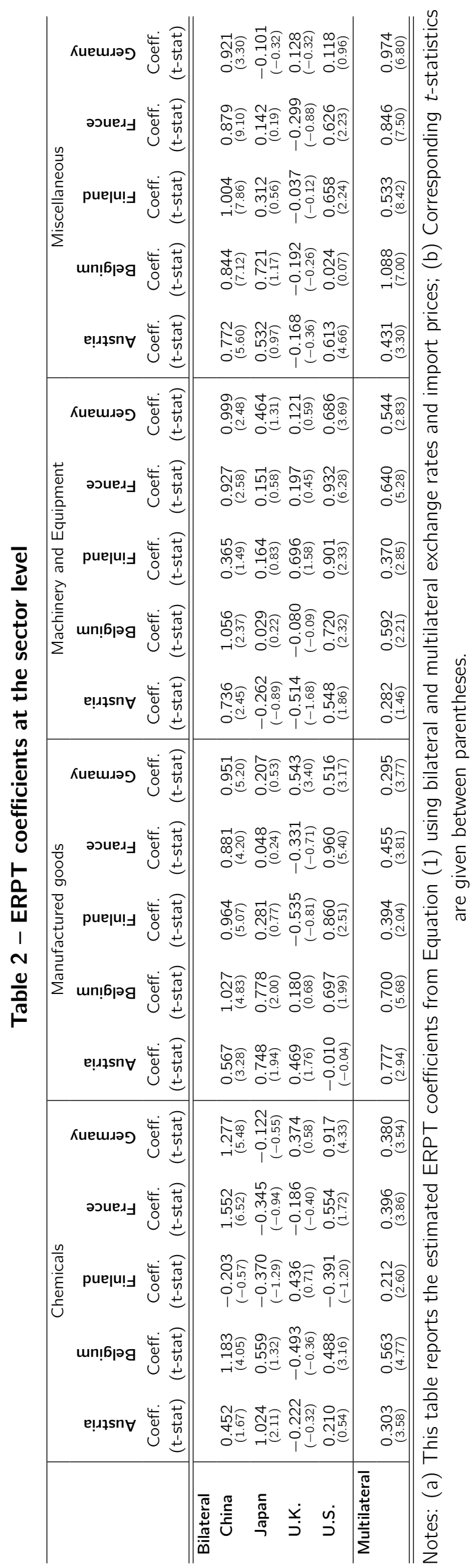




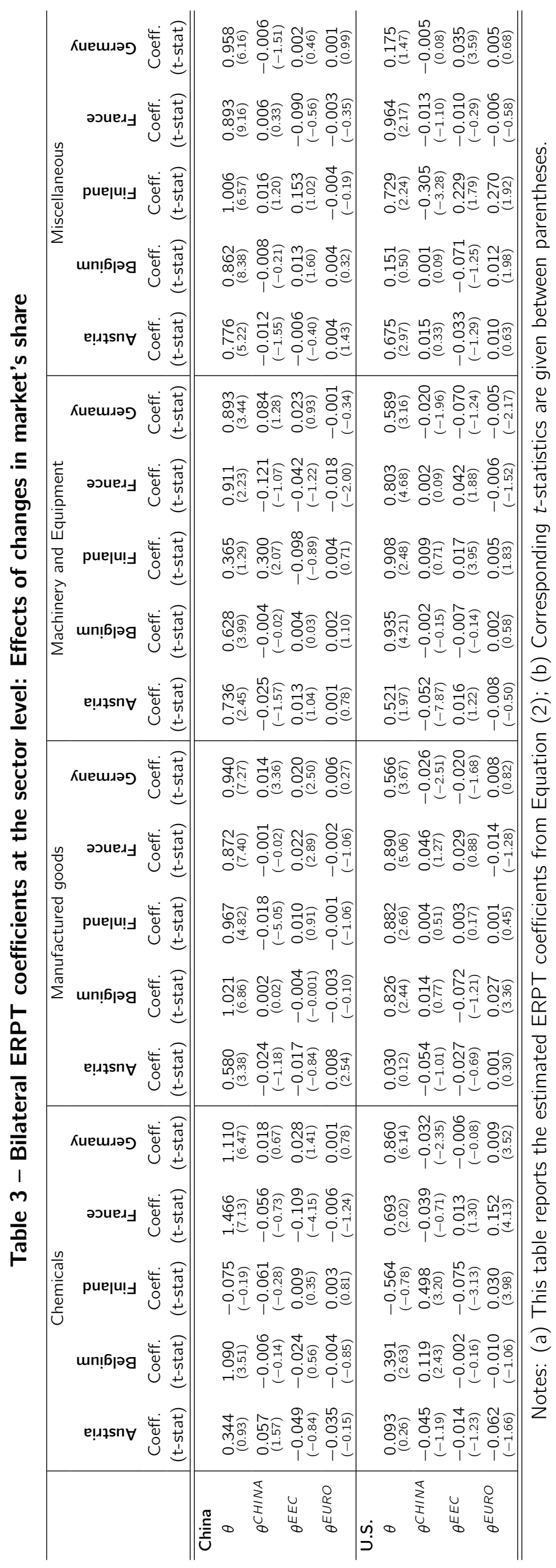

